\section{ANNALS OF THE UNIVERSITY OF CRAIOVA}

Series: $\checkmark$ Biology

$\checkmark$ Horticulture

$\checkmark$ Food products processing technology

$\checkmark$ Environmental engineering

Vol. XXVI (LXII) - 2021

\title{
OLD FORESTS FROM APUSENI MOUNTAINS
}

\author{
Enescu Raluca ${ }^{1}$, Vasile Diana ${ }^{1^{*}}$, Dincă Lucian ${ }^{1}$ \\ 1 "Marin Drăcea" National Institute of Research and Development in Forestry - Brașov \\ * Correspondence author. E-mail: diana_vasile@ymail.com
}

Keywords: Apuseni Mountains, old forest, common beech, sessile oak

\begin{abstract}
At a global level, the area of old forests has decreased as a result of high commercial value which led to an increase in the harvesting pressure. The present study was realized in Apuseni Mountains (Romanian Carpathians) by using data from forest management plans. Stands older than 190 years were taken into account. The analysed data refer to the occupied surface, species, relief characteristics (altitude, slope aspect, slope) and biometric data. The oldest stand is 300 years old and consists of sessile oak. Common beech is the species that occupies the largest areas, while the biggest diameters exceed $90 \mathrm{~cm}$.
\end{abstract}

\section{INTRODUCTION}

At a global level, the surface occupied by old forests has decreased due to a high commercial value which led to an increase of the exploitation pressure over them (Lindenmayer et al. 2012). Besides the anthropic factor, fires (Jones et al. 2016) or drought (Bennett et al. 2015) are the natural factors that threaten the conservation of old forests. From an ecologic perspective, they can influence the spatial and temporal distribution as well as the abundance of some tree species (Punchi-Manage et al. 2015). The importance of old forests as a habitat for animals is considerable, as they are true ,biodiversity hotspots" that sustain more species when compared with the neighbouring areas (Dean et al.1999).

Old forests must be managed in order to maintain their ecologic and socio-economic purpose. As such, these areas can be excluded from harvesting. The management of old forests must be approached with care and in relation with anthropic activities, without creating landscape traps (Lindenmayer et al. 2011). These landscape traps can cause fires or isles of old forests predisposed to fire (Thompson et al. 2007). These can make other neighbouring forest areas vulnerable.

Restoring these stands can last centuries, while knowing the ecological processes and the importance of this forest type is very important, justifying also the attention of this study. As such, management strategies are needed for reducing the fragmentation of old forests. These must be based on scientific studies that approach different variables from these stand types. In Romania, different studies (Cântar et al. 2019, Dincă et al. 2020, Timiș-Gânsac et al. 2020, Vechiu et al. 2021) have shown the characteristics of these stands, contributing to the international literature dedicated to this subject (Rosenberg et al. 1988, Pederson 2010, Barbati et al. 2012, Lindenmayer et al. 2014, Le Roux et al. 2014). 
Old forests offer the necessary space for a large diversity of trees (Dincă et al. 2020, Timiș-Gânsac et al. 2020), animals (Ciontu et al. 2020, Crișan et al. 2020), non-wood forest products (Blaga et al. 2018, Tiwary et al. 2020), medicinal plants (Vasile et al. 2017), mushrooms (Dincă et al. 2016) or forest fruits (Tudor et al. 2019, Enescu et al. 2020).

The purpose of this article is to characterise old stands from Apuseni Mountains, by using forest management plans as a source of information.

\section{MATERIAL AND METHODS}

Data from forest management plans realized during 1994-2007 from Apuseni Mountains are the base material for this article $\left({ }^{* * \star}\right.$ Amenajamente silvice). We have analysed all stands from the forest districts that belong to Apuseni Mountains and have old stand namely: Baia de Arieș, Bârzava, Gârda, Gurahonț, Hălmagiu, Sebiș-Moneasa, Sudrigiu and Vașcău. For this study, stand age was the main characteristic for defining old forests. As such, we have analysed stands with a minimum age of 190 years. Information about species, area, age, altitude, exposition, slope, distance from the road, average diameter and average height were organized in a database in Excel. This allowed for an easier management.

Apuseni Mountains belong to the Romanian Carpathians, the Western group (fig. 1). In the context of rebuilding mixture forests, Apuseni Mountains represent an important case study due to the reduced human intervention. As an example, mixed forests from Drăganului Valley have regenerated naturally in a compact area of 5000 ha (Abrudan \& Turnock 1999).

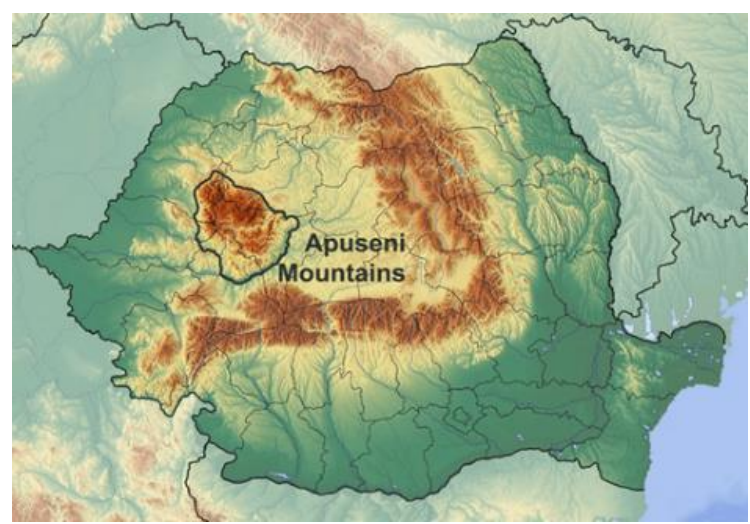

Figure 1. Apuseni Mountains (source: www.transylvania-mountainguide.com)

RESULTS AND DISCUSSIONS

The total area occupied by old forests (older than 190 years) from the forest districts located in Apuseni Mountains is of 154,1 ha. The area occupied by each species is rendered in Figure number 2. The largest area is occupied by common beech (Fagus sylvatica) with over 89 ha, while the second place is reclaimed by sessile oak (Quercus petraea) with approximately 45 ha. Two resinous species are also present, namely silver fir (Abies alba) and yew (Taxus baccata). This last species also occupies the smallest area, with only 0,6 ha. Other species are Turkey oak (Quercus cerris) and hornbeam (Carpinus betulus). 


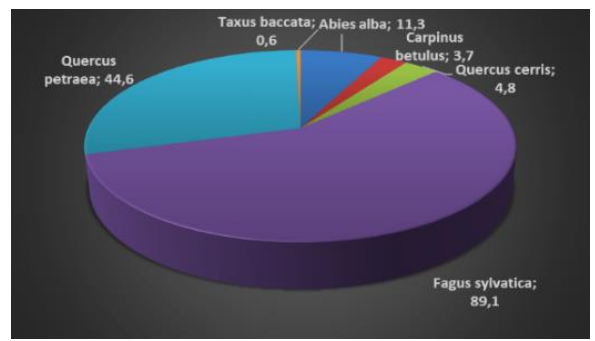

Figure 2. The surface (ha) occupied by species from old stands

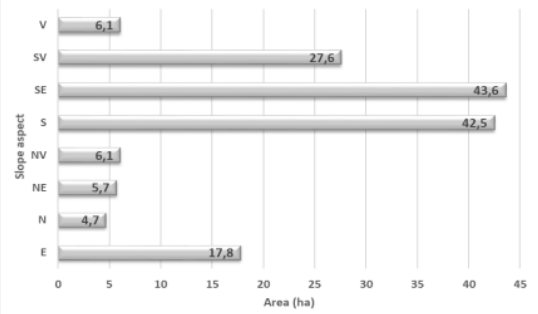

Figure 3. The distribution of old stands on slope aspect categories

The oldest age is of 300 years, found in a sessile oak stand from Vascău Forest District. The following species, aged 210, is a yew from the same forest district. The age categories are 300 years, 210 years, 200 years, 195 years and 190 years. The 300 year old stand occupies an area of 0,8 ha, the 210 year olds 0,6 ha, the 200 years 11,5 ha, the 195 years 9,5 ha, while the largest area (131,7 ha) is occupied by 190 years old stands. As a general tendency, it can be seen that as the age decreases when the area occupied by the stands increases. This affirmation is sustained by calculating the Pearson correlation coefficient between the two variables (stand age and the area occupied by them). As such, the value of this coefficient is $-0,17$. The fact that it is an inverted correlation (negative correlation coefficient) means that when a variable decreases (in this case, stand age), the other variable increases (occupied area).

In regard to the distribution of old forests on the 8 slope aspect categories (E, N, NE, NW, S, SE, SW, W) (fig. 3), we can observe that the largest area is occupied by SE (partially shadowed) and $S$ (sunny) slope aspect. On the other side, the lowest areas are distributed on shadowed slope aspect ( $\mathrm{N}$ and $\mathrm{NE}$ ). No species predominates on any slope category mentioned above, even though some species (silver fir, common beech, yew) have a shadow temperament (Șofletea et al. 2007). However, three species (silver fir, common beech, yew) can be found only on these shadowed slope aspect (N, NE). The oldest stands (210 and 300 years) are present on partially shadowed and shadowed spope aspects.

Categories for $100 \mathrm{~m}$ were realized for altitude, another relief characteristic representative for the studied forests (fig. 4). The largest area are located in the 500$599 \mathrm{~m}$ interval, followed by 400-499 m and 1200-1299 m. Practiclly, the largest surfaces with old stands (>190 years) are present on the forest's superior limit and towards the inferior limit. Common beech is the species with the most varied amplitude, being present in all altitude categories. On the other hand, fir appears only at altitudes of over $1000 \mathrm{~m}$, while holm does not exceed $680 \mathrm{~m}$. Furthermore, Hungarian oak is present only in the 300-399 m category.

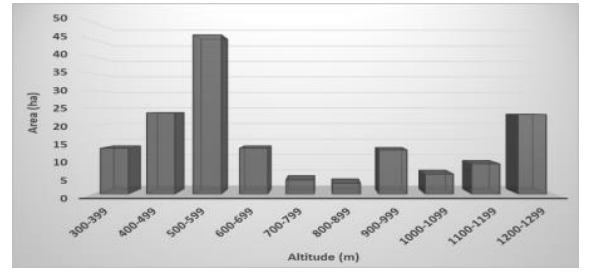

Figure 4. Distribution of old forests on altitude categories

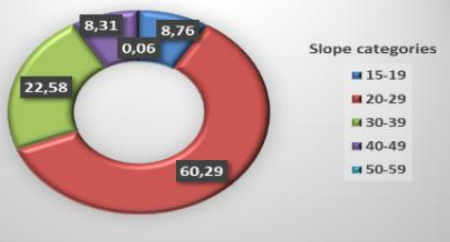

Figure 5. Distribution of old forests on slope aspect categories, expressed in surface percentages 
Field slope is the last studied relief characteristic. Similar to slope aspect and altitude, slope was also divided in more categories. The occupied area expressed in percentages from the total area was calculated for each category (fig. 5 ). As it can be seen in Figure 5, the $20-29^{\circ}$ slope category has the largest percentage (more than half) from the total surface occupied by old forests in Apuseni Mountains. The second place $\left(30-39^{\circ}\right)$ is situated at a large distance and represents over $22 \%$ from the total area. The $10-19^{\circ}$ and $20-29^{\circ}$ categories represent fields with fast slopes, occupying almost $70 \%$ of the total old forests from Apuseni Mountains. The $30-50^{\circ}$ category is represented by fields with a very fast slope and are $30 \%$ occupied by old forests. A single stand is located on a steep slope $\left(>50^{\circ}\right)$, namely a 210 year old yew stand from an area of only 0,1 ha.

Another important characteristic of these forest types is represented by the distance from roads. It is possible that this characteristic is one of the most important and that decides if these forests reach old ages, over their harvesting age. This is determined by their very low degree of accessibility. In Romania, the harvesting age is of maximum 100 years for common beech and sessile oak, 105 years for silver fir and only 65 years for Turkey oak and sessile oak (Nicolescu 2016). As it can be seen in Figure number 6, the largest area of old stands is situated in the $5-10 \mathrm{~km}$ category. This is a considerable distance, leading to high prices for transport costs. There are also stands situated at extremely large distances from the road, namely $42 \mathrm{~km}$ for a 190 years old common beech stand that occupies an area of 3,1 ha.

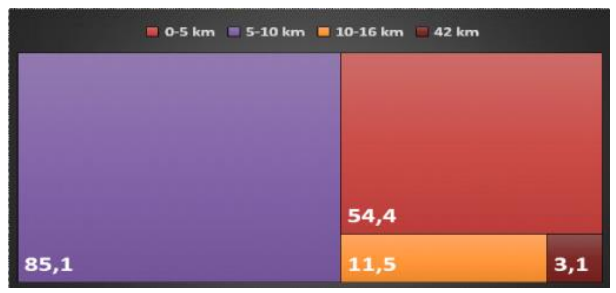

Figure 6. The distribution of old stands (hectares) based on the distance from roads

In regard to the biometric characteristics of these forests, the largest average diameters exceed $90 \mathrm{~cm}$ and can be found for common beech, sessile oak and Turkey oak. Furthermore, the highest average heights range between 30-35 m and are present at common beech, sessile oak and silver fir.

\section{CONCLUSIONS}

The total area occupied by old forests ( $>190$ years) in Apuseni Mountains is of 154,1 ha. These old forests are composed of six species: common beech, sessile oak, silver fir, Turkey oak, hornbeam and yew.

The oldest age is recorded for a sessile oak stand -300 years. The largest area occupied by old forests is found on partially shadowed and sunny slopes. As for altitude, the largest old forests are found at 500-599 m, on fields with a slope of $20-29^{\circ}$, at $5-10 \mathrm{~km}$ away from roads. 


\section{REFERENCES}

Abrudan I., Turnock D. 1999. A rural development strategy for the Apuseni Mountains, Romania. GeoJournal, 46(3), 319-336.

Barbati A., Salvati R., Ferrari B., Di Santo D., Quatrini A., Portoghesi L., Travaglini D., lovino F., Nocentini S. 2012. Assessing and promoting old-growthness of forest stands: lessons from research in Italy. Plant Biosystems-An International Journal Dealing with all Aspects of Plant Biology, 146(1), 167-174.

Bennett A. C., McDowell N. G., Allen C. D., Anderson-Teixeira K. J. 2015. Larger trees suffer most during drought in forests worldwide. Nature Plants, 1, 1-5.

Blaga T., Dincă L., Enescu M. C. 2018. Using the analytic hierarchy process to select the most important non-wood forest products for lasi county. Lucrări Științifice, Seria Horticultură, 61(2), 306-316.

Cântar I. C., Dincă L., Chisăliță I., Crișan V., Kachova V. 2019. Identifying the oldest stands from the Southern Carpathians together with their main characteristics. Proceedings of the Multidisciplinary Conference on Sustainable development, Filodiritto International Proceedings, pp. 186-193.

Ciontu C. I., Dincă L. 2020. Analyzing the importance of game and fish species from Harghita County. Scientific studies and research, Biology, 29(2), 23-27.

Crișan V., Marcu C., Dincă L.C. 2020. The characteristics of some animal species from Dolj County and the importance of their capitalization. Analele Universitatii din Craiova, seria Agricultura-Montanologie-Cadastru, 50(2), 87-92.

Dean W. R., Milton S. J., Jeltsch F. 1999. Large trees, fertile islands, and birds in arid savannah, pp. 61-78.

Dincă L., Enescu C. M., Dincă M., Cântar I. C. 2016. Mushrooms in Romanian toponymy, vocabulary and literature. Journal of Horticulture, Forestry and Biotechnology, 20(3), 119- 125.

Dincă L., Bratu I. 2020. Assessment of the distribution and characteristics of the oldest forests stand from the Romanian's Western Plain. Bulletin UASVM series Agriculture, 77(2), 9-14.

Dincă L., Breabăn I. G. 2020. Smart hornbeam stands (Carpinus betulus L.) from the West Plain. Present Environment and Sustainable Development, 14(2), 111-119.

Enescu R., Dincă L. 2020. An assessment of forest fruits from Arad County. Annals of the University of Craiova - Agriculture, Montanology, Cadastre Series, 49(2), 107-113.

Jones G. M., Gutiérrez R. J., Tempel D. J., Whitmore S. A., Berigan W. J., Peery M. Z. 2016. Megafires: An emerging threat to old-forest species. Frontiers in Ecology and the Environment, 14, 300-306.

Le Roux D. S., Ikin K., Lindenmayer D. B., Manning A. D., Gibbons P. 2014. The future of large old trees in urban landscapes. PloS one, 9(6), 99403.

Lindenmayer D. B., Laurance W. F., Franklin J. F. 2012. Global decline in large old trees. Science, 338, 1305-1306.

Lindenmayer D. B., Hobbs R. J., Likens G. E., Krebs C., Banks, S. C. 2011. Newly discovered landscape traps produce regime shifts in wet forests. Proc. Natl. Acad. Sci. USA, 108, 15887-15891.

Lindenmayer D. B., Laurance W. F., Franklin J. F., Likens G. E., Banks S. C., Blanchard W., Gibbons P., Ikin K., Blair D., McBurney L., Manning A. D. 2014. New policies for old trees: averting a global crisis in a keystone ecological structure. Conservation Letters, 7(1), 61-69. 
Nicolescu V. N. 2016. Silvicultură I. Biologia pădurii (ediția a 2-a). Aldus Press, Braşov, pp. 193.

Pederson N. 2010. External characteristics of old trees in the Eastern Deciduous Forest. Natural Areas Journal, 30 (4), 396-407.

Punchi-Manage R., Wiegand T., Wiegand K., Getzin S., Huth A., Gunatilleke C. V. S., Gunatilleke I. A. U. 2015. Neighborhood diversity of large trees shows independent species patterns in a mixed dipterocarp forest in Sri Lanka. Ecology, 96, 1823-1834.

Rosenberg D. K., Fraser J. D., Stauffer D.F. 1988. Use and characteristics of snags in young and old forest stands in southwest Virginia. Forest Science, 34(1), 224-228.

Timiș-Gânsac V., Dincă L., Cheregi G. 2020. Considerations concerning the oldest stands from Banatului Mountains, Romania. Sustainable Development Research, 2(1), 64-71.

Timiș-Gânsac V., Dincă L. 2020. Salcia albă din pădurile dobrogene. Buletin Ştiinţific. Revista de Etnografie, Ştiinţele Naturii şi Muzeologie (Serie Nouă), 45(32), 19-27.

Tiwary A., Vilhar U., Zhiyanski M., Stojanovski V., Dinca L., 2020. Management of nature-based goods and services provisioning from the urban common: a panEuropean perspective. Urban Ecosystems, 23(3), 645-657.

Tudor C., Constandache C., Dincă L. 2019. Benefits brought by the abundance and importance of forest fruits from Satu Mare county, Romania. Book of Proceedings of the $X$ International Scientific Agricultural Symposium "Agrosym 2019", 1920-1925.

Vasile D., Dincă L., Enescu M. 2017. Impact of collecting mushrooms from the spontaneous flora on forest ecosystems in Romania. AgroLife Scientific Journal, 6(1), 268-275.

Șofletea N., Curtu A. L. 2007. Dendrologie. Transylvania University Press, Brasov, pp. 630.

Thompson J. R., Spies T. A., Ganio L.M. 2007. Reburn severity in managed and unmanaged vegetation in a large wildfire. Proc. Natl. Acad. Sci. USA, 104, 1074310748.

${ }^{* * *}$ www.transylvania-mountainguide.com

*** Amenajamentele silvice ale ocoalelor: Baia de Aries (1998), Barzava (1996), Garda (2001), Gilau (2007), Gurahont (1994), Halmagiu (1994), Sebis-Moneasa (1994), Sudrigiu (1998), Vascau (2004). 